ISSN 1392-0340 (Print)

ISSN 2029-0551 (Online)

https://doi.org/10.15823/p.2019.136.5

Pedagogika / Pedagogy

2019, t. 136, Nr. 4, p. 67-88 / Vol. 136, No. 4, pp. 67-88, 2019

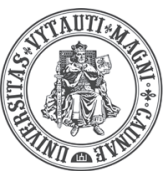

\title{
Spanish First Cycle Primary School Textbooks' Graphic Representations. A Study on Gender, Culture and Functional Diversity
}

Olga Moreno-Fernández ${ }^{1}$, Pilar Moreno-Crespo², Encarnación Pedrero-García ${ }^{3}$, Coral I. Hunt-Gómez ${ }^{4}$

1 Olga Moreno-Fernández, PhD. University of Seville, Department of Didactics of Social and Experimental Sciences. C / Pirotecnia S/N, 41018, Seville, Spain, omoreno@us.es

2 Pilar Moreno-Crespo, PhD. University of Seville, Department of Methods of Research and Diagnosis in Education. C/ Pirotecnia S/N, 41018, Seville, Spain, pmcrespo@us.es

3 Encarnación Pedrero-García, PhD. Pablo de Olavide University, Department of Education and Social Psychology. Carretera de Utrena, Km.1. 41013 Seville, Spain, epedgar@upo.es

4 Coral I. Hunt-Gómez, PhD. University of Seville, Department of Language Education. C/ Pirotecnia S/N, 41018, Seville, Spain, coralhuntg@us.es

Abstract. This paper analyses graphic representation of gender, functional and cultural diversity in Spanish Primary Education textbooks. A sample of 528 images from three different textbooks by three of the main publishing houses in Spain was studied. Results showed equal representation in terms of gender. However, textbooks still do not sufficiently include graphic representations of cultural or functional diversity. Greater efforts are needed to ensure that textbooks reflect the classroom's reality and that diversity normalized in schools.

Keywords: diversity, photographs, illustrations, textbooks, primary education.

\section{Introduction}

Educating for diversity implies a positive attitude towards communication and interaction between cultures. Understanding diversity as a necessary learning factor in today's school organizations is also paramount. Thus, schools will be as inclusive and intercultural as they accept diversity as an added value of enrichment and growth that favours school coexistence. However, currently, we are facing a complex challenge in Education for Diversity. On the one hand, it represents the desire of being a critical and 
inclusive educator and, on the other hand, teachers can find themselves at a crossroad of paths from folkloric exaltation to a merely compensatory curricular approach. Besides, social difficulties, as well as other conditioning factors, also exercise a profound influence on the orientation and the guidelines regarding intercultural education in schools (Leiva \& Pedrero, 2010).

According to the "National Action Plan for Social Inclusion of the Kingdom of Spain 2013-16" (Spanish Ministry of Health, Social Services and Equality, 2014), the groups with the highest vulnerability index are: 1) homeless, disabled, elderly or dependent people; 2) victims of violence; 3 ) people discriminated due to their race or ethnic origin, or to their sexual orientation or gender identity; 4) people with an addiction, and 5) prisoners or returning citizens. Taking this into consideration, this study reviews the graphic representations in Spanish Primary Education textbooks of the following categories: gender, functional and cultural diversity.

Over the last few years, when examining gender, the principle of equality ensures fairness between men and women, and this is reflected in the concept of parity (Martens, 2015). Regarding functional diversity, the Convention on the Rights of Persons with Disabilities (United Nations, 2006) recognizes the right to universal accessibility and design for all users, implying the need to strengthen disabled people's social participation. The adoption of this Convention implies the recognition and commitment of institutional policies to the promotion of accessibility and the achievement of a more inclusive society (Aparicio \& Martínez, 2017).

In the matter of cultural diversity, the current global migration crisis caused by territorial, political or religious conflicts created a new wold scenery that must not be overlooked. Even if it is not a recent phenomenon, it has affected those countries which are currently receiving refugees. Therefore, the social presence of diversity has dramatically increased and, consequently, the presence of cultural diversity in schools is higher. This new situation has forced socio-educative institutions and policy designers to show commitment to training in and for diversity, bearing in mind that the reference frame for life is the frame of diversity (Gullicks, Pearson, Child \& Schwab, 2007; Ballesteros-Velázquez, Aguado-Odina, \& Malik-Lévano, 2014; González-García, 2014; Martínez-Cifuentes, 2016; Martínez-Más, 2016; Sánchez, 2016; Lee, 2018). As an example, the European Union has been experiencing the growing incorporation of immigrant students into the different educative systems for the last decades and, therefore, schools have adapted to cultural diversity and designed a framework of common coexistence in which diversity is considered an asset (Llorent-Bedmar, 2013).

In Spain, the Law on the General Organization of the Educational System (LOGSE, 1990) introduced the term attention to diversity, intending to provide personalised support to persons belonging to different groups, according to their idiosyncrasies and needs. Subsequently, Organic Law 2/2006, of $3^{\text {rd }}$ May, on Education (LOE, 2006) defined the public school as a space for coexistence and learning. It also stated that the Right to 
Education needs to be guaranteed of all citizens, therefore diversity must be considered a paramount educational element. On this subject, in the aims and principles section, the LOE defines the terms person and society linking them to a set of values -justice, tolerance, freedom, peace, cooperation, solidarity and non-discrimination-, as well as to the democratic principles of coexistence: pluralism, participation, and respect.

In the three Education Laws that have been in force in Spain during the last two decades, diversity has been considered a positive asset in terms of coexistence, curricular innovation and promotion of community participation in an inclusive school, a school for all, where students, teachers, families and social agents are part of an open educational community (Leiva \& Pedrero, 2010). It is important to remember that, in those schools, the most frequently used resource in the classrooms still are the textbooks or school manuals, and that they contain a symbolic representation of a society and its culture. Textbooks are guides for content-related decisions as well as didactic strategies. In this way, on numerous occasions, textbooks predetermine educational practice in the classroom (Zabala, 2010). Hence, it can be stated that school textbooks are configured as invisible mechanisms through which inequalities appear and are reinforced (Terrón \& Cobano, 2008).

This research aims to identify, describe and analyse the graphic representation of gender, cultural and functional diversity in the textbooks of the first year of Primary Education (6 years) in Andalusia, Spain. To this end, an exploratory study has been carried out through an analysis of the content of the images. Previous textbook analysis research has been focused on the assessment of the ideological content they transmit and how accurately the different social collectives were represented. In this line, Torres Santomé (1989) pointed out the five main mechanisms of distortion of reality that are usually used in textbooks: suppressions (omitting or denying the existence of characters, events, objects to hide their significance and importance), additions (inventing the existence of events or events that are not such), deformations (selecting and ordering data in specific ways so that the meanings are distorted), diverted attention (calling attention to specific elements or events in order to blur or ignore real events), and blaming the complexity of the subject (a topic is not addressed and the excuse is that it is very difficult, both by its level of content together with the psychological and educational characteristics of the recipients).

By being aware of these mechanisms school textbooks' illustrations ought to sufficiently represent the social changes that are taking place in different contexts and to reproduce real, non-stereotyped models. Therefore, illustrations should reflect social changes and even anticipate those transformations that are slowly taking place in our environment. As an example of this, illustrations in textbooks showing men and women sharing domestic tasks or children's care would be pertinent and positive, as it would be the inclusion of different types of non-stereotypes functional or cultural diversity. Consequently, educational materials constitute a space for "the promotion of a human, 
open and tolerant disposition that knows how to duly respect and value other cultures and peoples, different and strange from one's own" (Calvo, 1989, 10). However, a large number of textbooks still provide negative or stereotyped images of minority cultures, which affects both students and teachers (Del Campo, 1999).

It is clear that school textbooks "can be perfectly studied and considered as a representation of the interests of society and also as subliminal and paradigmatic models of a way of thinking, of a mentality" (Selander, 1995, 130). Textbooks are a tool to provide a glimpse of the socially and culturally pre-established canon (Guijarro, 2005). Therefore, school textbooks include a hidden curriculum that must be examined. To achieve this purpose, it is necessary to consider not only what appears, but also what does not appear, since in many cases discrimination is given by the absence of a specific issue.

\section{Theoretical Analysis}

Images constitute a major element in the very definition of school textbooks, becoming a fundamental part of the task of transmitting content. Images are one of the most attractive aspects for students' attention, and this is particularly relevant to the early stages of education. It can be affirmed that images are motivating elements which reinforce values and ideas (Terrón \& Cobano, 2008).

As mentioned before, the objective of this study is to address how three different expressions of diversity are included in Spanish Primary Education textbooks. In the first place, the incorporation of gender equality in textbooks' images is explored. Then, the inclusion of functional diversity through images and cultural diversity will be analysed.

Incorporation of Gender Equality in Textbooks

The study of Gender diversity in textbooks became a research interest in Spain in the '80s (Benavente \& Núñez, 1992; García \& Roset, 1992; Garreta \& Careaga, 1987; Moreno-Marimón, 1986; Moreno-Sardá, 1987; Rodríguez-Izquierdo, 1998; Subirats, 1993). These first studies denounced textbooks' sexism and androcentrism, focusing on the number of representations of male in Primary and Secondary textbooks, which was way higher than the number of female representations (Hamodi, 2014; Vaíllo-Rodríguez, 2016).

In 1983 the Spanish Institute of Women was created, -an independent organization that is attached to the Ministry of Health, Social Services and Equality. From the very beginning, this institution seeks gender equality and the full participation of women in political, cultural, economic and social life. It has performed a leading role in making gender associated stereotypes visible and in overcoming inequalities in numerous areas, including education. The institution published a series of non-sexist education notebooks aimed at educators to help them eliminate sexist stereotypes within the field of education (Instituto de la Mujer, 2019). In 2013, the Institute of Women published the Recomendaciones para introducir la igualdad e innovar en los libros de texto (Vaíllo-Rodríguez, 2013), a 
series of recommendations for textbooks publishers that suggested strategies and tools for introducing equally and innovation in textbooks. Some of the strategies are specifically devoted to the incorporation of equality and a gender approach to graphic representations in textbooks (Vaíllo- Rodríguez, 2013, 125-155) and provide very specific instructions and scales for measuring the degree of commitment to the incorporation of gender equality in the publishing process. At the same time, Subirats (1993) stated that androcentrism was being reduced thanks to the II Equal Opportunities Plan passed by the Spanish Ministries Council at the beginning of 1993, together with the recommendations established by the of the Institute of Women to control what was included in textbooks. These circumstances made publishing houses modify their policies not to have any issues due to lack of adherence to the recommendations.

Later, Blanco (2000) and Peñalver (2001) affirmed, in the conclusions of their respective studies, that even if normative changes had been implemented demanding equal opportunities and social treatment, women's presence in textbooks was not much higher. This has been attributed to the fact that textbooks still transmitted non-representative cultural and ideological models to young people, and, consequently, these models are transmitted into society and education (Gómez-Carrasco \& Gallego-Herrero, 2016). This is consistent the results of several studies that examined iconic language in the last two decades (Espigado, 2004; Moya-Mata, Ros, Menescardi \& Bastida, 2013; Pedrero-García, Moreno-Fernández \& Moreno-Crespo, 2017; Pellejero-Goñi \& Torres-Iglesias, 2011; Táboas \& Rey, 2011; Terrón \& Cobano, 2009). These studies proved that images are not neutral; on the contrary, they have a great transmission value and normally reinforce traditional values. Furthermore, the existence of studies that highlight an increase of women's graphic representations in textbooks (Valls-Montás, 2001) does not necessarily mean that what if been currently represented is a real reflection, because in many cases, women representation is still incidental.

Despite of the changes gradually experienced by male and female roles and the progressively subtler manifestations of androcentrism, women's presence in textbooks as well as in the syllabus is still minimum (Marolla-Gajardo, 2016). In this regard, a very recent study shows that the number of images representing women decreases as the level in Secondary Education increase (López-Navajas, 2014). In the same manner, Ortega-Sánchez (2017) found that women in textbooks still fit in a classical male profile and that they belong to an elite. Notwithstanding the experienced advances in sexist representations in textbooks, there are still sexist conducts that are culturally enrooted that can be identified in some manuals (Blanco, 2000). Their permanence leads to gender stereotype reproduction within the educative system, and, consequently, to their reflection in textbooks (Lomas, 2000; García-Luque, 2005).

To sum up, it can be stated that, despite having experienced some advances in female representations in textbooks in Spain, there are still many steps to be taken if we are to achieve a real gender diversity inclusion in our schools and the curricula. 
Recent studies regarding gender equality incorporation in textbooks indicate that countries like South Africa, textbooks have not experienced any advance towards gender equality:

textbooks employ a variety of mechanisms to maintain a heteronormative patriarchal worldview, and each publication upheld these discourses to varying degrees. Some of the discourses used to sustain this perspective included the stereotypical gendered representations of boys and girls, queer invisibility, male autonomy versus a lack of female autonomy, failure to problematize rape culture and consistently portraying girls as the victims of male predators (Ting-Chong, 2018, 3).

\section{Incorporation of Functional Diversity in Textbooks}

Functional diversity has also been incorporated into the educative in the 1980s as several norms and recommendations of national and international institutions appeared. Article 49 of the Spanish Constitution was the first legislative step towards the social integration of people with functional diversity. This constitutional norm was fully endorsed with the publication of the Spanish Law of Social Integration for the Disabled [Ley 13/1982 de 7 de abril, de Integración Social de Minusválidos], also known as LISMI. In Spain, the educative sphere, the publication of the Organic Law 17/1990 of General Ordering of the Educative System (LOGSE) introduced the concept of special educative needs. All subsequent laws, LOE (2006) and LOMCE [Ley Orgánica 8/2013, para la Mejora de la Calidad Educativa] established principles for normalization and integration at school (Moya-Mata et al, 2017). During Primary Education, the importance of education in equal opportunities for men and women, as well as the no discrimination of those with disabilities is insisted on. The LOMCE (2013), in the $5^{\text {th }}$ Section of the Explanatory Memorandum of the Law, refers to the European Commission's European Disability Strategy 2010-2020, adopted in 2010, and states that education must also address persons with disabilities, guaranteeing them quality inclusive education and training (López, 2013).

People with disabilities usually have to confront negative attitudes that have their origins in social believes, prejudice and stereotypes. In this sense, the attitude of teachers, families, and pears in the school towards children with functional diversity is very important (World Health Organisation, 2011). The analysis of disability in textbooks in Spanish Early and Primary Education has been thoroughly studied by Martínez Bello $(2013,2013 a, 2014)$. The author states that textbooks do not include this community and that "bodies presenting some type of disability are silenced" (Martínez Bello, 2013, 213).

A study developed by Miralles, Delgado \& Caballero (2008) regarding 18 textbooks of Early Education belonging to six different publishing houses, concluded that $7.1 \%$ of the images represented people with disabilities, generally a girl or a boy in a wheelchair. In Primary Education, Martínez-Bello (2013a) analysed 1126 images of six Spanish publishing houses, and the results of the study showed that $98.9 \%$ of the images represented people with no disabilities and only $1.2 \%$ of the images included people with some type 
of disability. Regarding the type of disability, the author highlighted that $68 \%$ of the images that represent persons with disabilities showed people with physical disabilities, a $22 \%$ with mental disabilities and, finally, an $8 \%$ represented senses related disabilities. Regarding gender and disability, Martínez Bello (2013a) revealed that $72 \%$ of the images of textbooks included men and boys and $28 \%$ girls and women.

It is important to stress that, in our current society, schools are ruled by inclusive criteria. Nonetheless, taking into consideration the examined previous research, it can be observed that, regardless of the subject or the educative level, there is a recurrent lack of presence of people with disabilities. This makes the "reality" that appears in the books very different from the reality that is lived at schools (González-Palomares, 2015).

\section{Incorporation of Cultural Diversity in Textbooks}

Textbooks are still one of the most used resources in educative centres. They are a tool to transmit culture, comprehension, and ways of understanding the world (Ferreras Listán \& Jiménez Pérez, 2013; López Facal, 2010). Paradoxically, a study developed by Aguado (2005 apud Martínez Bello, 2013a) shows that cultural identity, which is an essential part of world knowledge, has not received enough attention in the syllabus, neither at schools, and that it is not frequently included in the activities teachers' plan.

The importance of textbooks lies in their comprehension of a particular ideology and in their aim of transmitting values assimilated by the society, as well as in the maintenance of the community's identity. In this sense, textbooks can be considered a political and social element. Dealing with ideology, politics, and values from a textbook it implies an act of power (Foster \& Cawford, 2006). Rodríguez Izquierdo $(2004,21)$ affirms that educative systems cannot be cantered in monocultural perspectives because these kinds of contexts are uncharacteristic of our societies, which necessarily include cultural diversity.

Tajeddin \& Teimournezhad (2015) examined several Iranian studies analysing how culture is taught using English Language Teaching materials. In the line of Rodríguez Izquierdo, they highlighted the "limitations of some textbooks in fostering intercultural understanding" (p. 183). Another study of English Language Teaching textbooks in Korea aimed to examine how different cultures were reflected in several aspects included in the books, such as race, nationality, gender as well as intercultural interactions (Song, 2013). Results showed a higher prevalence of white male representations, which can be considered unequal. Furthermore, when analysing intercultural interactions, most examples just included a superficial level of cultural engagement (Song, 2013).

From the academia, Pellicer Ugalde, Gigante, Díaz-Couder \& Olarte Tiburcio (2001) stated that the relationship between textbooks and cultural diversity is an element that influences the structure and ideology of the whole educative system. Moya Mata and her collaborators (2013) claimed that students' materials should be fundamentally aimed to enhance equal opportunities, and therefore, cultural diversity. 
In this respect, educative institutions face a tricky situation. Schools present a system with the final goal of equalising several levels, even at a cultural level; and, from a completely opposite point of view, the school context is constantly changing and is highly influenced by the political, economic and labour atmosphere of the sociocultural environment in which students, their families, social agents, teachers, and other actors live (Torres Santomé, 2008). This conflict is due to the confrontation of a system that advances in an unhurried way with another that develops extremely fast. The ideal solution would be for the school to assume the existent diversity and its influence on the daily development of educative centres (Galindo, 1992; Rodríguez Izquierdo, 2004).

\section{Methodology}

\section{Procedure}

In this study, a sample of 528 of graphic representations included in Primary Education Textbooks was analysed. Data were collected in the 2018-2019 school year. In the first place, a preliminary analysis was performed and three different levels of representation were identified. Afterward, three main aspects were examined in the following way.

The criteria by which the different group frames are graphically categorized arise from three main aspects:

1) Gender: diversity from a gender point of view, i.e. as a social and cultural construct, will be visualized in the number of representations of men, women, boys, and girls;

2) Functional diversity: functional diversity will be identified with people who need mobility resources (wheelchairs, canes, crutches...) and/or who make visual or auditory sensory diversity recognizable in the images; and

3) Cultural diversity: representation of people who may visibly belong to different cultures, religions, ethnic groups or communities.

After the preliminary analysis, three levels of representation of diversity were identified. The first one was a tendency towards parity. This is clearly shown by an equal representation of men and women, as well as boys and girls. The second level of representation deals with making cultural or functional diversity visible, as the social commitment to a diverse society in a globalized world is expressed in the appearance of some "representatives" of it, but only a few examples. Finally, the third level of representation showed diversity associated with stereotypes. One of the most noteworthy issues is the association made between situations of poverty and developing countries, characterizing the populations represented with features attributed to specific geographical and cultural situations. Another remarkable aspect is the assimilation between geographical-cultural aspects and the physical characteristics of people. 


\section{Planned data analysis}

In her doctoral thesis, Prendes (1994) established a general textbook analysis model and a specific instrument for descriptive image analysis. This model is currently used as a reference for the analysis of textbooks' images in Spain. Applying Prendes' model, the number of graphic elements is examined, differentiating photographs and pictures into separate groups. This model was also applied for data collection and categorizing. To better suit the aim of the research, some aspects of the instrument were adapted. Thus, a procedure was created ex profeso, which contained three main sections to be studied in three different dimensions.

The first one consisted of analysing the publication for identifying its main data, which included publisher, collection, publication year as well as editorial and illustration team. The second one was the analysis of the graphic characteristics of the images including colour, structuring graphics, relational graphics. The third dimension, which was the most relevant for the purpose of this study, was the interpretation of the message of the image. It included the environment and context of the image, the type of action taking place, the characters taking part in the action, which is the main character of the action and similar aspects. This third dimension provides information about the worldviews transmitted by the textbooks in an educational level, in which images are strongly linked to the students' environments and conceptions.

In terms of gender equality, the number of men, women, girls and boys' representations was established. Traditional male and female roles were studied regarding family, social and work-related aspects. For functional diversity, the presence of people with physical or sensorial disabilities was established in numeric terms. Finally, cultural diversity was examined in terms of the appearance of cultural models different from the white middle-class traditional one. In these two last aspects, the mere presence of the characters belonging to minorities is considered relevant.

\section{Sample}

The sample consists of 528 images included in three textbooks published by three of the main Spanish publishing houses in Education - Anaya, Santillana, and Edelvives-. All three examined books have been published once the Spanish Education Law 2/2006 was valid (see Table 1) and were in use at Primary Schools until the complete enter into force of the current Educative Law, LOMCE, which had a transition period that lasted until 2018 for all educational Levels. One of the most interesting characteristics of these textbooks is that the subjects of Social Sciences and Natural Sciences and Cultural Aspects were combined in a sole manual. This provided students a complete and global perspective of their environment. Textbooks published once the current law was fully applied divided the content into two subjects, therefore the previous one was more suitable for the purposes of this analysis. Criteria used for the selection of textbooks were: belonging to the area of knowledge of the Natural, Social and Cultural environment; being aimed at students 
in the First Cycle of Primary Education, having published only one book per academic year, being published in Spanish language, meeting the requirements established by the Spanish educational system and having been used at Primary Schools during the aforementioned period of time. Of the 528 graphic elements analysed, $48.1 \%$ corresponded to photographs, while $51.9 \%$ were illustrations. If we analyse textbooks individually, the ones published by Anaya and Edelvives contained a greater number of illustrations, while in the case of Santillana photographs had a greater presence.

Table 1

Sample of the research

\begin{tabular}{llcccc}
\hline \multicolumn{1}{c}{ Editorial } & \multicolumn{1}{c}{ Collection } & Year & $\begin{array}{c}\text { Number of } \\
\text { Photographs }\end{array}$ & $\begin{array}{c}\text { Number of } \\
\text { Pictures }\end{array}$ & $\begin{array}{c}\text { Total graphic } \\
\text { elements }\end{array}$ \\
\hline Anaya & Salta a la vista & 2008 & 39 & 95 & 134 \\
\hline Santillana & La casa del Saber & 2007 & 151 & 25 & 176 \\
\hline $\begin{array}{l}\text { Edelvives } \\
\text { Total elements } \\
\text { analyzed }\end{array}$ & Mundo Agua & 2007 & 64 & 154 & 218 \\
\hline
\end{tabular}

\section{Results}

This section covers the data obtained by each of the three frames examined: gender, functional and cultural analysis.

\section{Gender equality}

In all graphic elements studied, gender is approached in an egalitarian manner, as the number of male and female figures and the roles they exercise are proportionate (Table 2). Therefore, trends in numbers are very similar. Even though, male representations reached $52.2 \%$ and female $47.8 \%$, which shows a slight imbalance that favours male presence.

Table 2.

Male and female representations in the analysed textbooks

\begin{tabular}{lccccc}
\hline & $\begin{array}{c}\text { Total } \\
\text { Graphic } \\
\text { resprentation }\end{array}$ & $\begin{array}{c}\text { Number } \\
\text { of male } \\
\text { characters }\end{array}$ & $\begin{array}{c}\text { Percentage } \\
\text { of male } \\
\text { characters }\end{array}$ & $\begin{array}{c}\text { Number } \\
\text { of female } \\
\text { characters }\end{array}$ & $\begin{array}{c}\text { Percentage } \\
\text { of female } \\
\text { characters }\end{array}$ \\
\hline Anaya (Salta a la vista) & 134 & 189 & $52.9 \%$ & 168 & $47.1 \%$ \\
\hline Edelvives (Mundo Agua) & 218 & 237 & $54.7 \%$ & 196 & $45.3 \%$ \\
\hline $\begin{array}{l}\text { Santillana (La casa del } \\
\text { saber) }\end{array}$ & 176 & 202 & $48.9 \%$ & 211 & $51.1 \%$ \\
\hline Total & 528 & 628 & $52.2 \%$ & 575 & $47.8 \%$ \\
\hline
\end{tabular}


An example of this equal representation of gender can be observed in Figure 1, which displays a family scene with equal distribution of roles (man and woman cook and children are setting the table) where a woman, a girl, a man, and a boy are represented. This fair treatment is extended to the rest of the images studied. Results in this section indicate that, although there is abundant room for further progress on gender issues, especially in the elimination of gender roles, the current balance of gender representation in textbooks is a clear indicator of the commitment of publishing houses to gender equality. In general, therefore, it can be stated that the Spanish textbook publishers were in the same line of thinking of the future recommendations of the Women's Institute, that were to be published in 2013 .

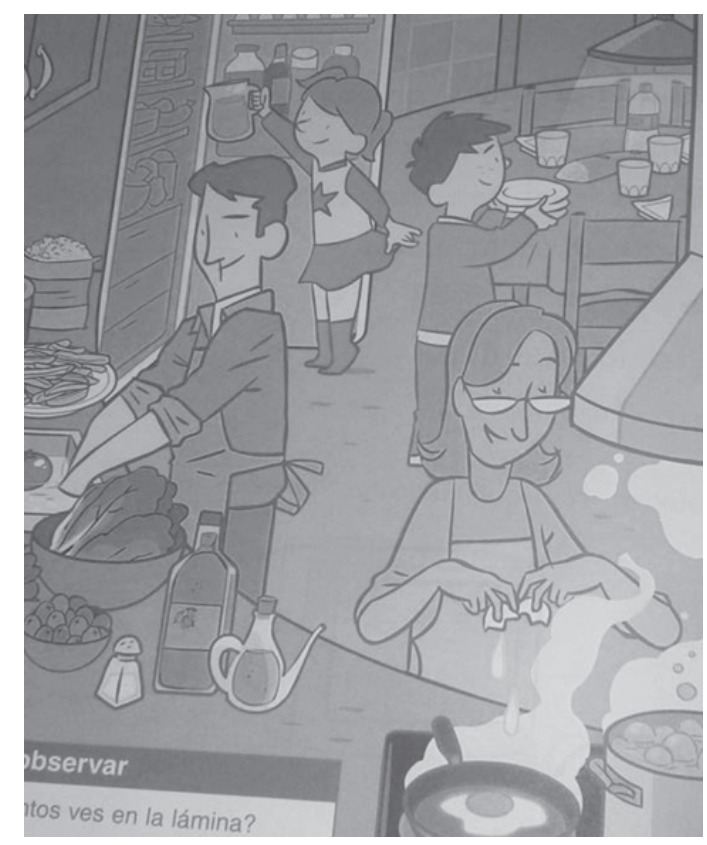

Figure 1. Example of gender diversity in school textbook images

(Fragment extracted from the Anaya Textbook, Salta a la Vista, 2008, 28).

\section{Cultural Diversity}

Results show that, even if cultural diversity is present in textbooks, it is far from being at the same level as gender representation. Remarkably, cultural diversity is represented in every examined textbook. In all the analysed graphics, at least one person with differentiated physical features per manual appeared. Statistical data show that cultural diversity reaches a representation of less than one-tenth of the total (9.1\%). Anaya publishing house has even a more reduced cultural diversity representation (5.6\%), whereas in Edelvives and Santillana cultural diversity receives higher representation (Table 3). 
Table 3.

Cultural diversity in the analysed textbooks

\begin{tabular}{lccc}
\hline & $\begin{array}{c}\text { Total graphic } \\
\text { resprentations }\end{array}$ & $\begin{array}{c}\text { Number of non-white- } \\
\text { middle class characters }\end{array}$ & $\begin{array}{c}\text { Percentage of non-white- } \\
\text { middle class characters }\end{array}$ \\
\hline Anaya (Salta a la vista) & 357 & 20 & $5.6 \%$ \\
\hline Edelvives (Mundo Agua) & 433 & 44 & $10.2 \%$ \\
\hline $\begin{array}{l}\text { Santillana (La casa del } \\
\text { saber) }\end{array}$ & 413 & 45 & $10.9 \%$ \\
\hline Total & 1203 & 109 & $9.1 \%$ \\
\hline
\end{tabular}

The representation of cultural diversity made is materialised in the presence of a child of apparent African or Asian origin (Figure 2). It can be stated that school textbooks have advanced in recent decades regarding the representation of cultural diversity. Nonetheless, publishers need to include a wider cultural range in their textbooks as a multicultural and multi-ethnic community is already present in the Spanish classrooms.

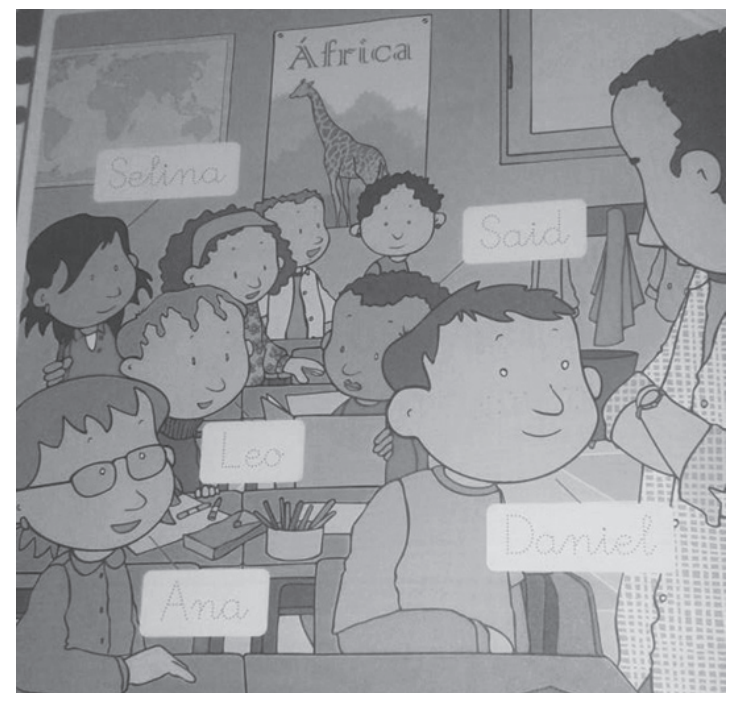

Figure 2. Example of cultural diversity

(Fragment extracted from the Edelvives Textbook, Water World Collection, 2007, 4).

It is interesting to note that there seems to be an association between cultural diversity and some specific geographical and cultural contexts. Patronizing and behaviours linked to altruism, charity, and solidarity are observed when referring to developing countries. In this way, the idea that certain cultures are associated with poverty, strengthening a Eurocentric vision where the "whites" are the ones who are going to help other needy populations. As it can be observed in Figure 3, the above-described attitudes are reinforcing stereotypes. 


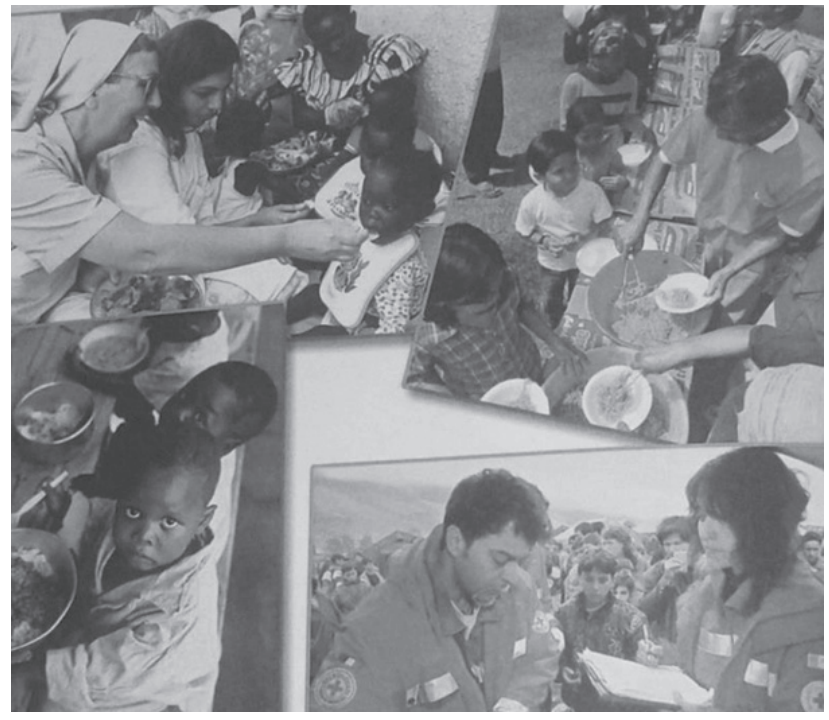

Figure 3. Example of cultural diversity

(Fragment extracted from Santillana Textbook, The House of Knowledge, 2007).

\section{Functional Diversity}

The third field examined is functional diversity and its representation is anecdotal. Functional diversity is rarely represented in the analysed images. Anaya has no representation at all, whereas Edelvives has a representation of three characters (1 visually impaired and two wheelchair users) and Santillana includes ten characters (2 visually impaired, seven wheelchair users and one character that presents an artificial limp). In total, ten characters present physical dysfunctionality and three with sensorial dysfunctionality.

Table 4.

Functional diversity in the analyzed textbooks

\begin{tabular}{lccc}
\hline & $\begin{array}{c}\text { Total Graphic } \\
\text { resprentation }\end{array}$ & $\begin{array}{c}\text { Number of non-white- } \\
\text { middle class characters }\end{array}$ & $\begin{array}{c}\text { Percentage of } \\
\text { non-white-middle } \\
\text { class characters }\end{array}$ \\
\hline Anaya (Salta a la vista) & 357 & 0 & $0 \%$ \\
\hline Edelvives (Mundo Agua) & 433 & 3 & $0.7 \%$ \\
\hline Santillana (La casa del saber) & 413 & 10 & $2.4 \%$ \\
\hline Total & 1203 & 13 & $1.1 \%$ \\
\hline
\end{tabular}

The low number of people with reduced mobility or people with sensory functional diversity is surprising (see Figures 4 and 5). Despite the efforts made by educational regulations in Spain to incorporate students with functional diversity into the "ordinary" 
school classrooms, inclusion still seems to be far from becoming a reality within the educational environment. The analysis reveals that the inclusion of graphic representations in the case of functional diversity, whether physical or sensorial, is practically non-existent.

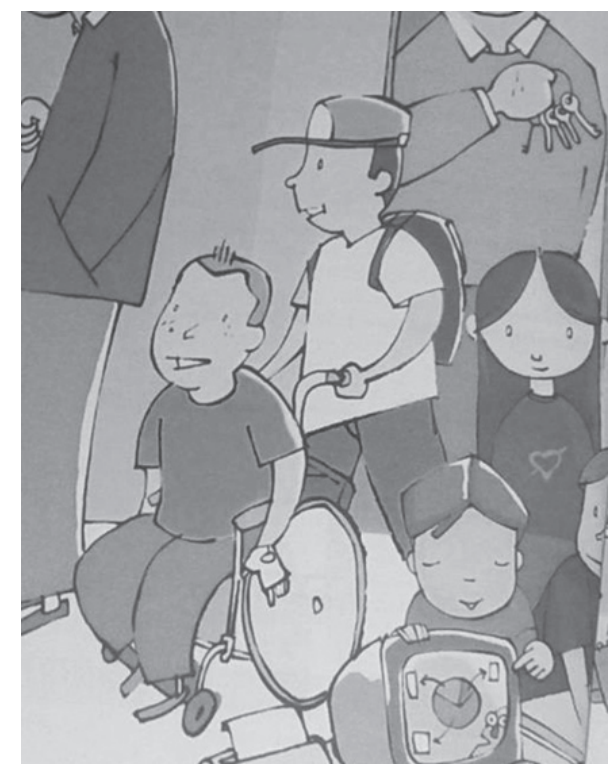

Figure 4. Example of functional diversity

(Fragment extracted from the Anaya manual, Salta a la vista Project, 2008).

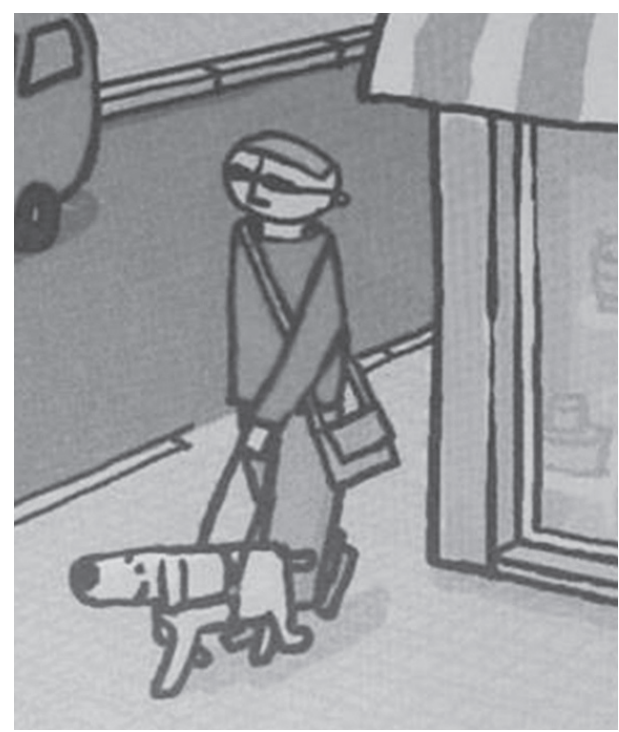

Figure 5. Example of functional diversity

(Fragment extracted the Edelvives manual, Water World Project, 2007). 
Only $1.1 \%$ of the represented characters present some type of functional diversity, lowering this percentage to $0.1 \%$ if we refer to school-age children. This means that there is an invisibilization of these collectives in the school textbooks. They are not to be found in the educational classrooms, which results in a serious damage to this collective, since the non-represented reality does not exist, "to be visible means to be recognized in one's own person in the just expression of oneself in various contexts of life" (Radtke, Barbuto, Napolitano \& Iglesias, 2003, 2). Therefore, there is still an unacknowledged barrier to the recognition and integration of people with functional diversity in general.

\section{Discussion and Conclusions}

The present research aimed to examine graphic representation of gender, cultural and functional diversity in three textbooks for Primary Education published by three of the main publishing houses in Spain that were used at schools in a period of transition between the LOE and the LOMCE Educative Laws (2006-2018). A sample of 528 graphic representations was analysed following the model developed by Prendes (1994).

The study has found that, although a significant part of the school textbooks researched is changing the way diversity is treated, graphic representation of cultural and functional diversity is still insufficient, partial, plain and fragmented. In the case of gender, consistent with recent literature (Martens, 2015; Aparicio, \& Martínez, 2017), there are elements of parity included in textbooks representations in the public and private spheres; women and girls are performing activities and developing jobs that are traditionally not considered female one, and the same goes for men and boys. These findings are extremely encouraging as they are a reflection of the construction of a gender-fair society or, at least with the commitment of moving towards one. The work developed by the Institute of Women, manuals, and recommendations, still has a great deal of influence in the achievement of parity in the representation of gender in textbooks. Despite these promising results, much has to be done to eliminate gender roles both at home and at the family level (Manassero, \& Vázquez, 2002; Terrón, \& Cobano, 2008; Vaillo-Rodríguez, 2016; Gebregeorgis, 2016).

In the case of cultural and functional diversity, one of the most significant findings to emerge from this study is the nearly complete absence or distorted presentation of immigrants in the curricula, textbooks, and other school materials. This underrepresentation or misrepresentation may damage the self-image and self-esteem of students belonging to ethnic minorities, and may negatively influence their academic success.

Greater efforts are needed to ensure that this situation changes. A key priority should be incorporating elements and symbols of the cultures of origin into school life, in the curriculum, and textbooks (Llorent-Bedmar, 2013). Lemmer, Edwards \& Rapule (2008) acknowledge that the book's quality directly affects the teaching's quality. Thus, the findings of this study have several important implications for future practice, such as 
the adaptation of graphic representations for them to include the new socio-educational realities that reflect the diversity and richness of our current society. From the many courses of action that must be taken, we would like to highlight the importance of textbooks' representations of the society as, in most cases, they lay the foundations for the way lessons are developed and are the guiding materials for the daily routines in the classroom. Another possible action could be the implementation of a complementary strategy in which good teaching practices are identified to encourage the use of textbooks from the perspective of diversity (Covacevich \& Quintela, 2014).

The sample of the study consists of 528 graphic representation from three textbooks published by the main houses in Spain. This could be enlarged by the inclusion of smaller publishers in further research. Despite the limitations derived from the size of its sample, this study offers an insight into the representation of diversity in textbooks. It corroborated that the representation of diversity in textbooks does not correspond to current reality, as globalization and migratory movements have altered the way diversity is understood and have reconfigured local and global relations. Even if at a legislative level diversity is considered and included in the educative sphere in Spain, there is still a need to transfer the norm into textbooks and manuals. Consequently, educational organizations should take on the challenge of educating citizens according to the reality they are going to be facing.

As a future research line, once the transition period has elapsed, it would be interesting to examine the textbooks published in accordance with the criteria of the LOMCE. Also, other aspects of graphic representation in textbooks could be analysed such as different ages, relevance of the image according to the place in the unit, how they are linked to the text and the characteristics of the environment according to integration, accessibility and, multicultural criteria.

\section{Disclosure statement}

No potential conflict of interest was reported by the authors. The paper presents research and analysis conducted by the authors. As such, any comment, opinion, and position presented are that of the researchers and do not necessarily reflect the official policy or position of any persons associated with the programs or organizations featured.

\section{References}

Aparicio, M., \& Martínez, E. (2017). Universal Accessibility: Normative Sense and Implication in Education and the Professional Practice. Revista Española de Discapacidad, 5, 25-41. http:// doi.org/10.5569/2340-5104.05.01.02 
Ballesteros-Velázquez, B., Aguado-Odina, T., \& Malik-Liévano, B. (2014). Escuelas para todos: diversidad y educación obligatoria. Revista Electrónica Interuniversitaria de Formación del Profesorado 17(2): 93-107. https://doi.org/10.6018/reifop.17.2.197351

Benavente, J.M., \& Núñez, A. (1992). "El androcentrismo en la enseñanza de la historia y la geografía”. In: M. Moreno (ed.), Del silencio a la palabra. Coeducación y reforma educativa. Madrid: Instituto de la Mujer, 153-176.

Blanco, N. (2000). El sexismo en los materiales educativos en la ESO. España, Sevilla: Instituto Andaluz de la Mujer.

Calvo, T. (1989). Los racistas son los otros. Gitanos, minorías y Derechos Humanos en los Textos Escolares. Madrid, Spain: Popular.

Covacevich, C. \& Quintela, G. (2014). Desigualdad de género, el currículo oculto en textos escolares chilenos. Chile: Banco Interamericano de Desarrollo, Chile.

Cruickshank, V., Pedersen, S., Cooley, D. et al. (2019). How do Male Primary Teachers Negotiate Expectations to Perform Gendered Roles in Their Schools? Aust. Educ. Res. https:/doi. org/10.1007/s13384-019-00337-z

Del Campo, J. (1999). “Multiculturalidad y conflicto: percepción y actuación”. In: M. Á. Essomba \& E. Barandica. Construir la escuela intercultural: reflexiones y propuestas para trabajar la diversidad étnica y cultural. Barcelona, Spain: Graó, 47-54.

Espigado, G. (2004). "Historia y genealogía femenina a través de los libros de texto". In: C. Rodríguez (coord.). La ausencia de las mujeres en los contenidos escolares. Argentina, Buenos Aires: Miño and Dávila, 113-144.

Ferreras Listán, M., \& Jiménez Pérez, R. (2013). How is Heritage Conceptualized in Primary School Textbooks? Revista de Educación, 361, 591-618. https://doi.org/10.4438/1988-592XRE-2013-361-234

Foster, S. \& Crawford, K. (2006). “The Critical Importance of History Textbook Research”. In S. Foster \& K. Crawford (Eds.), What Shall We Tell the Children? International Perspectives on School History Textbooks. Greenwich, Inglaterra: Information Age Publishing, 1-23.

Galindo, A. (1992). "Condicionamientos Socioculturales del Sistema Escolar con Referencia a la Educación Intercultural”. In: X Congreso de Pedagogía Educación intercultural en la perspectiva de la Europa Unida. Salamanca: Imprenta provincial, 251-263.

García, C., \& Roset, M. (1992). “Sexismo y coeducación en el área de Ciencias Sociales”. In: M. Moreno (ed.). Del silencio a la palabra. Coeducación y reforma educativa. Madrid: Instituto de la Mujer, 140-152.

García-Luque, A. (2015). "Mujeres visibles e invisibles en la enseñanza de la Historia en la Educación primaria: cambios y pervivencias al amparo de la LOMCE”. In: C.R. García, A. M. Hernández \& J.L. de la Montaña (Eds.). Una enseñanza de las ciencias sociales para el futuro: recursos para trabajar la invisibilidad de personas, lugares y temáticas, Cáceres: Universidad de Extremadura, 165-173.

Garreta, N. \& Careaga, P. (1987). Modelos masculinos y femeninos en los textos de EGB. España, Madrid: Instituto de la Mujer. 
Gebregeorgis, M. Y. (2016). Gender Construction Through Textbooks: The Case of an Ethiopian Primary School English Textbook. Africa Education Review 13 (3-4), 119-140. https://doi.or $\mathrm{g} / 10.1080 / 18146627.2016 .1224579$

González-García, I. (2014). The Arrival of Immigrants at the Isala de Tierra in Alhucemas: Migratory Crisis between Spain and Morocco and Violations of Human Rights. Revista electrónica de estudios internacionales, 27, 1-28.

Gómez-Carrasco, C. J., \& Gallego-Herrero, S. (2016). The Persistence of Gender Stereotypes in Teaching History. A Study Trough Textbooks and Perceptions of Students in Compulsory Secondary Education in Spain. Revista electrónica Educare, 20(3), 1-28. http://dx.doi. org/10.15359/ree.20-3.1

González-Palomares, A. (2015). Cultura corporal y estereotipos en las fotografías de los libros de texto de educación física editados durante la ley orgánica de Educación. Doctoral Thesis. Pontevedra: Universidad de Vigo.

Guijarro, J. R. (2005). La representación axiológica del género y la orientación sexual en libros de textos de inglés para Secundaria. Porta Linguarum 4, 151-166. http://hdl.handle. net/10481/29873

Gullicks, K. A.; Pearson, J. C.; Child, J. T. \& Schwab, C. R. (2005). Diversity and Power in Public Speaking Textbooks. Communication Quaterly, 53 (2), 247-248. http://doi. org/10.1080/01463370500089870

Hamodi, C. (2014). Transmiten los libros de texto el valor de la igualdad desde la perspectiva de género? estudio del lenguaje icónico de dos editoriales. REIRE: revista d'innovació i recerca en educación, 7(1), 30-55. http://doi.org/10.1344/reire2014.7.1713

Instituto de la Mujer (2013). Manual para introducir la igualdad e innovar en los libros de texto. Madrid, Spain: Ministerio de Sanidad, Servicios Sociales e Igualdad.

Instituto de la Mujer (2019). Materiales didácticos. Available at: http://www.inmujer.gob.es/ areasTematicas/AreaEducacion/MaterialesDidacticos/MaterialesDidacticos.htm

Lee, J. F.K. (2018). Gender Representation in Japanese EFL textbooks - a Corpus Study. Gender and Education, 30 (3), 379-395, https://doi.org/10.1080/09540253.2016.1214690

Leiva, J. J. \& Pedrero, E. (2010). “De la extranjería a la ciudadanía: la cultura de la diversidad como fundamento para la construcción de la interculturalidad”. In: M. T. Terrón (Ed.). Diversidad cultural y atención socioeducativa. Una visión desde diferentes prismas. Sevilla, Spain: Fundación SM, Universidad Pablo de Olavide y Diputación de Sevilla, 31-50.

Lemmer, M., Edwards, J.A. \& Rapule, S. (2008). Educators' Selection and Evaluation of Natural Science textbooks. South African Journal of Education, 28, 175-187.

LOGSE-Ley Orgánica 1/1990, de 3 de octubre, de Ordenación General del Sistema Educativo, Boletín Oficial del Estado, $238 \$ 24172$ (1990).

LOE-Ley Orgánica 2/2006, de 3 de mayo, de Educación, Boletín Oficial del Estado, $106 \$ 7899$ (2006).

LOMCE-Ley Orgánica 8/2013, de 9 de diciembre, para la Mejora de la Calidad Educativa, Boletín Oficial del Estado, $295 \$ 7337$ (2013). 
Llorent-Bedmar, V. (2013). Immigration and Education for Diversity in the European Union. En-clave pedagógica: Revista Internacional de Investigación e Innovación Educativa 13, 31-44. Lomas, C. (2002). “El sexismo en los libros de texto”. In A. González \& C. Lomas (Coord.), Mujer y educación: educar para la igualdad, educar desde la diferencia. España, Barcelona: Graó, 193-209.

López, E.T. (2013). "La atención a la diversidad en la futura LOMCE". In: Ma C. Cardona, E. Chiner \& A. Giner (eds.), XVI Congreso Nacional/II Internacional Modelos de Investigación Educativa de la Asociación Interuniversitaria de Investigación Pedagógica (AIDIPE): Innovación Educativa al Servicio de Instituciones y Comunidades Globales, Plurales y Diversas (pp. 218-224). Alicante: AIDIPE.

López Facal, R. (2010). Nationalism and Europeisms in Textbooks: Identification and National Identity. Clio \& asociados: La historia enseñada, 14, 9-33. http://www.memoria.fahce.unlp. edu.ar/art_revistas/pr.4018/pr.4018.pdf

López-Navajas, A. (2014). Analysis of the Absence of Women in the ESO Textbooks: a Hidden Genealogy of Knowledge. Revista de Educación, 363, 282-308. https://doi.org/10-4438/1988592X-RE-2012-363-188

Manassero, M. A. \& Vázquez, Á. (2002). Gender Stereotypes and Language in Science Textbooks. Cultura y Educación 14 (4), 415-429. https://doi.org/10.1174/113564002762700880

Marolla-Gajardo, J. P. (2016). The inclusión of women in the Teaching of History and Social Sciences. Collective case study on the Possibilities and Limitations in the Chilean Classroom. Doctoral Thesis. Universidad Autònoma de Barcelona, Barcelona.

Martínez Bello, V. (2013). Silenced Bodies and Inclusive Education: Picture Analysis of Spanish Primary Education Textbooks. Revista Latinoamericana de Educación Inclusiva, 7(2), 213-229. Recuperado de http://www.rinace.net/rlei/numeros/vol7-num2/art12.pdf

Martínez Bello, V. (2013a). Representación racial, diversidad corporal y género en las imágenes de libros de texto españoles de educación infantil. Diálogos sobre educación. Temas actuales en Investigación Educativa, 4(7), 1-17.

Martínez Bello, V. (2014). The Relationship Between Childhood and Movement in Second Grade Early Childhood Education Textbooks. Actualidades investigativas en educación, 14(2), 1-20. Recuperado de http://revista.inie.ucr.ac.cr/index.php/aie/article/view/657

Martínez-Cifuentes, A. (2016). Refugiados/as sin refugio. Libre pensamiento 87, 38-43.

Martínez-Más, S. (2016). El aislamiento de Merkel: Refugiados y 'Brexit’ evidencian el declive de la 'autoridad' de Berlín. El siglo de Europa 1144, 46-48.

Mertens, F. (2015). Gender Parity or the Contribuition to Equity Principle. Aequalitas: Revista jurídica de igualdad de oportunidades entre mujeres y hombres 36, 37-42.

Miralles, P., Delgado, C., \& Caballero, Ma . R. (2008). The Analysis of the Family Concept on the Images of Text Books in Early Childhood Education. Enseñanza de las ciencias sociales, 7, 89-98. Recuperado de http://www.raco.cat/index.php/EnsenanzaCS

Moreno-Marimón, M. (1986). Cómo se enseña a ser niña: el sexismo en la escuela. Barcelona: Icaria Editorial. 
Moreno-Sardá, A. (1987). La investigación en España sobre mujer y educación. España, Madrid: Instituto de la Mujer.

Moya-Mata, I., Ros Ros, C., Menescardi, C. \& Bastida, A. I. (2013). Images in Primary Physical Education Books from a Gender Perspective. Tándem,Didáctica de la Educación Física, 41, 41-48.

Moya Mata, I.; Ros Ros, C.; Bastida Torróntegu, A. \& Menercardi Royuela, C. (2013). Sex and Race Stereotypes in Images of Textbooks in Primary Physical Education. Retos. Nuevas tendencias en Educación Física, Deporte y Recreación, 23, 14-18.

Moya-Mata, I.; Ruíz Sanchis, L.; Marín Ruiz, J.; Pérez Alonso-Geta, P. M. \& Ros Ros, C. (2017). Representation of Disabilities in Physical Education Textbook Image: Inclusión or Exclusión? Retos, 32, 88-95.

Ortega-Sánchez, D. (2017). Las mujeres en la enseñanza de la Historia y de las Ciencias Sociales. Estudio de caso en formación inicial de maestros y maestras de Educación Primaria. Doctoral Thesis. Universitat Autònoma de Barcelona, Barcelona.

Pedrero-García, E., Moreno-Fernández, O., \& Moreno-Crespo (2017). Education for cultural diversity an dinterculturality in the Spanish school context. Revista de Ciencias Sociales, 23 (2), 11-26.

Pellicer Ugalde, A.; Gigante, E.; Díaz-Couder, E. \& Olarte Tiburcio, E. (2001). Libros de texto y diversidad cultural: los libros en lenguas indígenas. Revista mexicana de investigación educativa, 6(12), 283-315.

Pellejero-Goñi, L.\& Torres-Iglesias, B. (2011). Sex education: sex and gender in Primary Education Textbooks. Revista de Educación, 354, 399-427.

Peñalver, R. (2001). Análisis del sexismo en los libros de texto de la ESO. España, Murcia: Secretaría Sectorial de la Mujer y de la Juventud.

Prendes, M. P. (1994). La imagen didáctica. Análisis descriptivo y evaluative. Doctoral Thesis. Murcia, Spain: Department of Didactics and School Organization, University of Murcia.

Radtke, D.; Barbuto, R.; Napolitano, E. \& Iglesias, M. (2003). Information Kit Violence means death of the soul. In Disabled Girls and Women-Victims of Violence-Awareness Raising Campaign and Call for Action. Daphne programme. DPI-UEC (2003). file://C:/Users/Olga/Downloads/ en_final_report_dpitalia_2000_052.pdf

Rodríguez-Izquierdo, R. (1998). La imagen y el papel de la mujer en los libros de texto escolares en España. Escuela Abierta, 1, 257-265.

Rodríguez-Izquierdo, R. M. (2004). Atención a la diversidad cultural en la escuela. Propuestas de intervención socioeducativas. Educación y futuro: revista de investigación aplicada y experiencias educativas, (10), 21-30.

Sánchez, A. (2016). La crisis migratoria divide Europa. El siglo de Europa 1144, 49-50.

Selander, S. (1995). “Análisis del texto pedagógico”. In: J. García Mínguez and M. Miranda Beas. Libros de texto y construcción de materiales curriculares. Granada: Proyecto Sur de Ediciones. 
Spanish Ministry of Health, Social Services and Equality. (2014). Plan Nacional de Acción para la Inclusión Social del Reino de España, 2013-16. Informes, estudios e investigación. Madrid, Spain: Ministerio de Sanidad, Servicios Sociales e Igualdad.

Song, H. (2013) Deconstruction of cultural dominance in Korean EFL textbooks, Intercultural Education, 24 (4), 382-390, http:/doi.org/10.1080/14675986.2013.809248

Subirats, M. (1993) (coord.). El sexismo en los libros de texto: análisis y propuesta de un sistema de indicadores. España, Madrid: Ministerio de Asuntos Sociales, Instituto de la Mujer.

Táboas, M. I., \& Rey, A. (2011). Pictures in Physical Education textbooks for mandatory Secondary Education: body models and physical activity. Revista de Educación, 354, 293-322.

Tajeddin, Z., \& Teimournezhad, S. (2015) Exploring the hidden agenda in the representation of culture in international and localised ELT textbooks, The Language Learning Journal, 43 (2), 180-193, DOI: 10.1080/09571736.2013.869942

Terrón, M. T., \& Cobano, V. (2008). The woman role in illustration of textbooks in primary education, Foro de Educación 10, 385-400.

Terrón, M. T. \& Cobano, V. (2009). El papel de la mujer en las imágenes de los textos escolares de Educación Primaria. Estudio comparado entre España y Marruecos. Educatio Siglo XXI, 27(1), 231-248.

Ting Chong, K. B. (2018) Decolonising Gender In Education: Contextualising Gender In The Grade 7 Life Orientation Textbooks. Final Project. Universidad de Pretoria.

Torres Santomé, J. (1989). Libros de texto y control del curriculum. Cuadernos de Pedagogía 168, 50-55.

Torres Santomé, J. (2008). Cultural Diversity and Curricular Content. Revista de Educación, 345, 83-110.

United Nations Organization. (2006). Convention on the Rights of Persons with Disabilities. https://www.un.org/development/desa/disabilities/convention-on-the-rights-of-personswith-disabilities.html

Vaíllo Rodríguez, M. (2013). Recomendaciones para introducir la igualdad e innovar en los libros de texto. Madrid: Instituto de la Mujer.

Vaíllo-Rodríguez, M. (2013). Libros de texto e igualdad. Análisis y propuestas para las editoriales españolas desde la perspectiva de género. Doctoral thesis. Universidad Complutense de Madrid: Madrid.

Vaíllo-Rodríguez, M. (2016). La investigación sobre libros de texto desde la perspectiva de género: ¿hacia la renovación de los materiales didácticos? Tendencias pedagógicas, 27, 97-124. http:// dx.doi.org/10.15366/tp2016.27.003

Valls-Montés, R. (2001). Los estudios sobre los manuales escolares de historia y sus nuevas perspectivas. Didáctica de las ciencias experimentales y sociales, 15, 23-36.

World Health Organization (2011) World Report on Disability. https://www.who.int/disabilities/ world_report/2011/en/

Zabala, M. Á. (2000). Diseño y desarrollo curricular. Madrid, Spain: Narcea. 


\title{
Ispanijos pirmosios pakopos pradinių mokyklų vadovèlių grafiniai vaizdai. Lyčių, kultūros ir funkcinès įvairovès tyrimas
}

\author{
Olga Moreno-Fernández ${ }^{1,}$ Pilar Moreno-Crespo ${ }^{2}$, Encarnación Pedrero-García ${ }^{3}$, \\ Coral I. Hunt-Gómez ${ }^{4}$
}

1 Dr. Olga Moreno-Fernández, Sevilijos universitetas, Socialinių ir eksperimentinių mokslų didaktikos katedra, C/ Pirotecnia S/N, Sevilija, ES-41018, Ispanija, omoreno@us.es

2 Dr. Pilar Moreno-Crespo, Sevilijos universitetas, Ugdymo tyrimo metodų ir diagnostikos katedra, C/ Pirotecnia S/N, Sevilija, ES-41018, Ispanija, pmcrespo@us.es

3 Dr. Encarnación Pedrero-García, Sevilijos Pablo de Olavide universitetas, Ugdymo ir socialinès psichologijos katedra, Carretera de Utrena, Km.1., Sevilija, ES-41013, Ispanija, epedgar@upo.es

4 Dr. Coral I. Hunt-Gómez, Sevilijos Coral I. Hunt-Gómez universitetas, Kalbų ugdymo katedra, C/ Pirotecnia S/N, Sevilija, ES-41018, Ispanija, coralhuntg@us.es

\section{Santrauka}

Šiandieninèje mokykloje labai svarbus teigiamas požiūris ị bendravimą, kultūrų sąveiką bei ịvairovès supratimą. Tai yra svarbiausias mokymosi veiksnys. Vadinasi, mokyklos bus ịtraukiančios ir tarpkultūrinės: jos priims ịvairovę kaip papildomą praturtinančią vertybę, skatinančią mokyklų sambūvị. Vis dèlto šiuo metu mūsų laukia sudètingas iššūkis, nes ugdymo ìvairove turi rasti pusiausvyrą tarp folklorinio išaukštinimo ir kompensuojamojo mokymo programų traktavimo.

Šio tyrimo tikslas - apžvelgti paveikslèlių pavyzdžius, atrinktus iš Ispanijos pradinio ugdymo vadovèlių. Didžiausias dèmesys buvo skirtas trims skirtingiems aspektams: lyčių, funkcinès ir kultūrinès įvairovès. Iš viso buvo išanalizuoti 528 paveikslèliai iš trijų skirtingų vadovèlių, kuriuos publikavo pagrindinès Ispanijos leidyklos.

Tyrimas patvirtino, kad Ispanijos pradinès mokyklos vadovèliuose padaryta didelè pažanga užtikrinant vienodą vyrų ir moterų atstovavimą. Rezultatai parodẻ lygų lyčių atstovavimą. Vis dèlto dar yra kur tobulèti, jei norima, kad moters vaidmuo atitiktų realybę. Ispanijos vadovèliuose vis dar nepakankamai pateikiama kultūrinès ar funkcinès ịvairovès grafinių iliustracijų. Būtina ịdèti daugiau pastangų, kad vadovèliai perteiktų realybę klasėse ir kad ịvairovè taptų standartizuota mokyklose.

Esminiai žodžiai: ịvairove, nuotraukos, iliustracijos, vadoveliai, pradinis ugdymas.

Gauta 20191030 / Received 30102019

Priimta 20200214 / Accepted 14022020 